\title{
Evaluation of dental status of the first permanent molar and the support area for a group of children aged between 7 and 12 years old
}

\author{
Evaluarea statusului odontal al molarului unu permanent şi al zonei de \\ sprijin la un lot de copii cu vârsta cuprinsă între 7 şi 12 ani
}

\author{
Andreea Pop ${ }^{1}$, Radu Septimiu Câmpian', Mariana Păcurar², Ecaterina Ionescư ${ }^{3}$, \\ Ştefan Milicescu ${ }^{3}$, Mihaela Păstrav ${ }^{4}$, Olimpia Bunta $^{4}$, Paula Jiman ${ }^{5}$, Viorica Țărmure ${ }^{4}$ \\ ${ }^{1}$ Disciplina Reabilitare Orală, Sănătate şi Management, \\ Universitatea de Medicină şi Farmacie „Iuliu Haţieganu“, Cluj-Napoca, România \\ 2Disciplina Ortodonţie, Universitatea de Medicină şi Farmacie, Târgu-Mureş, România \\ ${ }^{3}$ Disciplina Ortodonţie, Universitatea de Medicină şi Farmacie „Carol Davila“, Bucureşti, România \\ 4Disciplina Ortodonţie, Universitatea de Medicină şi Farmacie „Iuliu Haţieganu“, Cluj-Napoca, \\ România 5 Universitatea de Medicină şi Farmacie „Iuliu Haţieganu“, Cluj-Napoca, România
}

\begin{abstract}
Objectives. The purpose of this study was to evaluate the dental status of the first permanent molar and the support area for a group of children aged between 7 and 12 years old, who presented themselves at the Orthodontic Discipline of the University of Medicine and Pharmacy „Iuliu Haţieganu“ Cluj-Napoca, Romania, between 2016 and 2017.

Material and method. A group of 100 patients was formed, in which the evaluation of the dental status of the six year old molar was made both clinically and radiologically using 100 panoramic radiographies. Results and discussions. The statistic data reveals the following: at the age of 7-8 years old, $3 \%$ of the patients included in the group showed at least one first permanent molar extraction, the percentage of extraction reaching $11 \%$ at the age of 12 years old. $11 \%$ of the patients presented complicated caries at the level of the first permanent molar, and the support area was affected in $52 \%$ of the cases.

Conclusions. The first permanent molar is the most prone tooth to caries in the permanent dentition, which often leads to the decision to extract these compromised teeth without the possibility of conservative treatment.
\end{abstract}

Keywords: early extraction, permanent first molars, complicated caries, support area of occlusion

\section{REZUMAT}

Obiective. Scopul acestui studiu a fost acela de a aprecia statusul odontal al molarului de şase ani şi al zonei de sprijin la un lot de copii cu vârsta cuprinsă între 7 şi 12 ani, care s-au prezentat la Disciplina de Ortodonţie din cadrul Universităţii de Medicină şi Farmacie „Iuliu Haţieganu“ Cluj Napoca, în perioada 2016-2017.

Material şi metodă. S-a constituit un lot de 100 de pacienţi la care aprecierea statusului odontal a molarului de şase ani s-a facut atât clinic, cât şi radiologic, utilizându-se 100 de radiografii panoramice

Rezultate şi discuţii. Prelucrarea statistică a datelor relevă următoarele: la vârsta de 7-8 ani, 3\% dintre pacienții cuprinşi în lot au evidențiat cel puțin o extracție de molar prim permanent, procentul extracţiei ajungând la $11 \%$ la vârsta de 12 ani. $11 \%$ dintre pacienţi au prezentat carii complicate la nivelul molarului prim permanent, iar afectarea zonei de sprijin a fost de $52 \%$.

Concluzii. Primul molar permanent este cel mai predispus dinte la carie în dentaţia mixtă, acest lucru ducând de multe ori la decizia extracţiei acestor dinţi compromişi, cu imposibilitatea tratamentului conservativ.

Cuvinte cheie: extracţie timpurie, molari primi permanenţi, carie complicată, zona de sprijin a ocluziei

Toți autorii au avut contribuții egale 


\section{INTRODUCERE}

Erupția dinților deciduali, pierderea lor şi erupția ulterioară a dentiției permanente sunt evenimente ordonate, secvenţiale şi specifice vârstei. Trecerea de la dentiția primară la cea permanentă începe odată cu apariția şi erupția primilor molari permanenți şi a pierderii incisivilor deciduali, urmată de erupția incisivilor permanenți. Dinții permanenți sau succesivi înlocuiesc dinții de lapte într-o secvență de erupție care prezintă variații mari. Vârsta de erupție a primilor molari permanenți este unul dintre punctele de bază prin care se evaluează dezvoltarea fizică normală a copilului (1).

Primul molar permanent (PMP) a fost raportat a fi dintele cel mai predispus la carie din dentiția permanentă şi mixtă. Mai mult de $50 \%$ dintre copiii cu vârsta peste 11 ani prezintă cel putin o leziune carioasă la acest dinte. În plus, PMP a fost, de asemenea, descoperit ca fiind în mod semnificativ hipoplazic, cu aproximativ 6\% dintre copii având hipoplazie la unul sau mai mulți molari primi permanenți (2).

O revizuire sistematică recentă privind evaluarea riscului cariilor a identificat în mod clar vârsta posteruptivă ca predictor pentru caria la dinții permanenți - cu primii molari având un risc mai mare de carii ocluzale în primul an şi molarii de 12 ani în al doilea şi al treilea an după erupție. Aceste perioade de risc crescut coincid cu durata erupției primului şi a celui de-al doilea molar permanent. O multitudine de dovezi anecdotice susțin o asociere între stadiul erupțiilor şi dezvoltarea cariilor dentare, dar totuşi puține studii au investigat direct această problemă. Într-un studiu al lui Carvalho et al. (1989), s-a arătat că proporția leziunilor active a scăzut, în timp ce apariția leziunilor stagnante a crescut, deoarece molarii au ajuns la o ocluzie completă (3). Un studiu recent efectuat de L.S. Alves şi colaboratorii a arătat că molarii parțial erupți prezintă un risc mai mare pentru activitatea cariilor decât molarii în ocluzie completă. Aceste constatări indică faptul că acumularea de biofilme neperturbate este probabil responsabilă pentru riscul crescut de carii la molari permanenți în erupție (4).

Pedodontul şi ortodontul prezintă o dilemă majoră când exista molari primi permanenți cu carii complicate la un copil. Dilema are loc atunci când dinții sunt restaurați, dar rezultatele realizabile vor lăsa dinții cu prognostic discutabil. Primul molar permanent este rareori dintele ales pentru extracția în scop ortodontic. $\mathrm{Cu}$ toate acestea, există diferite situații clinice în care trebuie luate în considerare extracțiile de PMP. Aceste situații includ PMP cu carii complicate, PMP hipoplazici, PMP cu restaurări mari, unde premolarii sunt perfect sănătoşi, patologii apicale sau PMP trataţi endodontic, înghesuirea zonelor distale ale arcadelor şi molarii trei de formă rezonabilă şi în poziție rezonabilă, malocluzii divergente scheletic şi ocluzia deschisă anterioară (2). Mai mult decât atât, după cum relatează şi multe alte studii, primul molar permanent este susceptibil la defecte cronologice ale smalțului, hipomineralizare molară-incisivă şi carii, ceea ce poate necesita extracție forțată în dentiția în curs de dezvoltare. Din acest motiv, trebuie să se ia în considerare extracția electivă a primilor molari permanenți, cu un prognostic pe termen lung discutabil, atunci când se planifică extracții forțate.

Prezența oricărei malocluzii trebuie, de asemenea, evaluată în contextul planificării extracției (4). Totuşi, extracția primului molar permanent cu tratament ortodontic ulterior la pacienții tineri poate fi considerată o alternativă rentabilă la plasarea restaurărilor complexe care necesită înlocuire pe durata vieții (5).

Până în prezent, nu există un consens în literatura de specialitate care să sugereze că extracţia timpurie a PMP distrus/restaurat poate conduce la modificari ale dinamicii dento-maxilare în dentiția permanentă, dacă este urmată de tratament ortodontic corespunzător (2).

\section{MATERIAL ŞI METODĂ}

Am realizat un studiu pe un lot selectat de 100 pacienți cu vârste între 7 şi 12 ani care s-au prezentat pentru tratament ortodontic la Disciplina de Ortodonție din cadrul Universității de Medicină şi Farmacie „Iuliu Hațieganu“ Cluj Napoca, în perioada 2016-2017. Selecția pacienților s-a realizat pe criterii privind statusul odontal al zonei de sprijin şi al molarilor permanenți - carii complicate sau extracții ale molarului de şase ani. S-au realizat 100 de radiografii panoramice. Acest studiu a urmărit rata extracției timpurie a primilor molari permanenți, prezența cariilor complicate la nivelul primilor molari permanenți şi compromiterea zonei de sprijin. 


\section{REZULTATE}

Din totalul radiografiilor examinate, 3\% dintre pacienții cu vârsta cuprinsă între 7 şi 8 ani au evidențiat cel puțin o extracție de molar prim permanent, iar la pacienții cu vârsta de 12 ani s-a evidențiat un procent de $11 \%$ al extracției de cel puțin un molar prim permanent (Fig. 1).

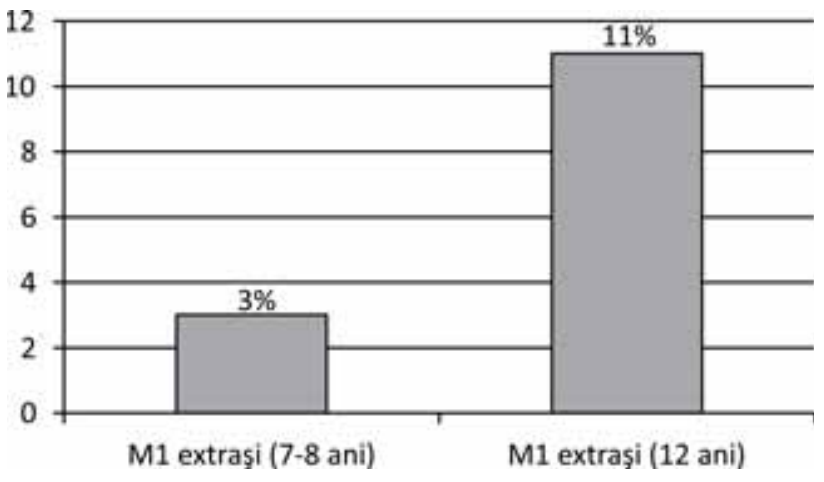

FIGURA 1. Situația extracțiilor de molari primi permanenți

În ceea ce priveşte caria complicată a molarilor primi permanenți, s-a observat o afectare de $11 \%$ a acestora (Fig. 2).

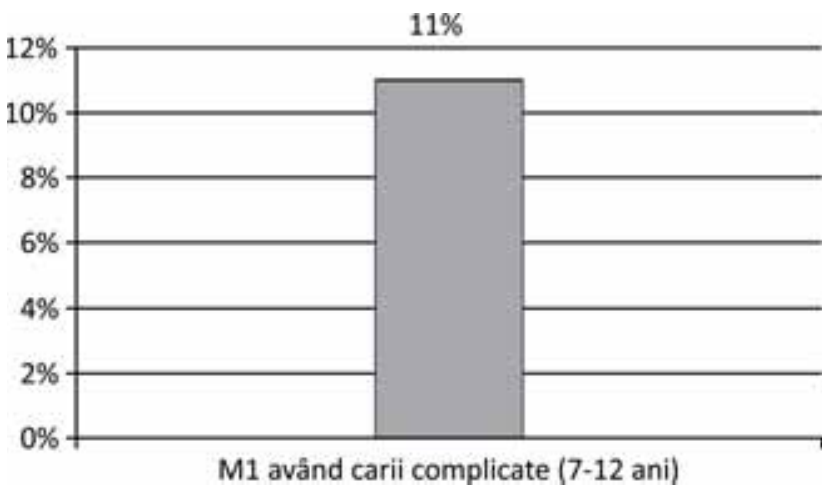

FIGURA 2. Situația molarilor primi permanentți prezentând carii complicate

Un alt aspect urmărit al prezentului studiu a fost evaluarea statusului odontal al dinților din zona de sprijin, obținându-se un procent de $52 \%$ de dinți afectaţi din lotul studiat (Fig. 3).

\section{DISCUŢII}

Analizând situația odontală a dinților din zona de sprijin, se observă în studiul nostru o afectare de $52 \%$ a acestora, rezultatele obținute fiind comparate cu alte studii din literatura de specialitate. Într-un studiu din Polonia, pe un număr de 284 de copii de 7-8 ani din şcoli alese în mod aleator în districtul

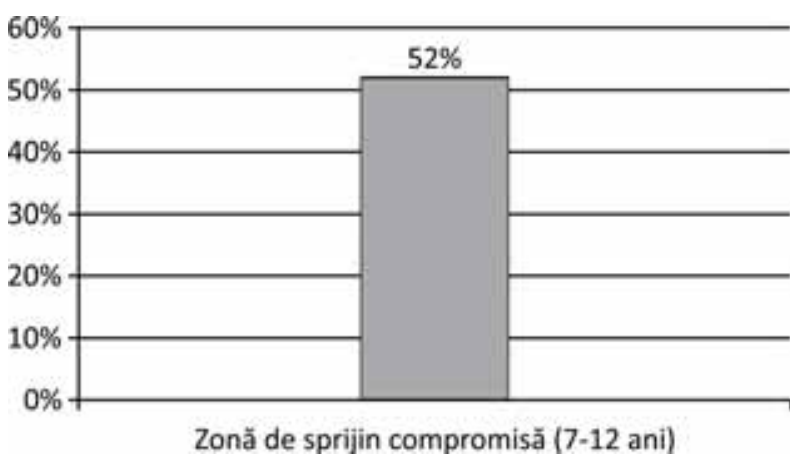

FIGURA 3. Afectarea zonei de sprijin

Bialystok, s-a constatat că, în 2011, afecțiunile odontale cu implicarea pulpei dentare au fost considerate cea mai gravă etapă în proporție de $26,4 \%$ (dinţi primari). Această valoare a fost mai scăzută în comparație cu studiul nostru (52\%). Procentul cariei complicate la molarii de şase ani din studiul nostru (11\%) prezintă valori mai ridicate comparativ cu studiul din Polonia (0,3\%) (6).

Epuizarea tuturor mijloacelor conservative de tratament a cariilor complicate de PMP impun extracția acestora. O alta cauză de extracție sunt hipoplaziile severe de PMP, iar rezultatele studiul efectuat de Jalevik şi Moller în 2007 relevă faptul că momentul optim pentru efectuarea extracțiilor este între 8 şi 10 ani, cu închiderea fiziologică a breşei. Studiul a inclus 27 de copii în vârstă de 5,6-12,7 ani care au avut unul sau patru molari primi permanenți (PMP) extraşi din cauza hipomineralizării molareincisive severe (MIH); fiecare caz a fost urmărit după indicaţiile individuale la 3,8-8,3 ani după extracție. Acest studiu a arătat că extracția de PMP grav afectați de MIH este o alternativă bună de tratament. Este de aşteptat o reducere favorabilă spontană a spaţiului şi dezvoltarea poziţionării dentaţiei permanente fără intervenție în majoritatea cazurilor cu extracție înainte de erupția celui de-al doilea molar (7). Studiile analizate au aratat că extracția primului molar permanent ar fi avut o bună reducere spontană a spațiului şi ar fi condus la o dezvoltare favorabilă a dentiției permanente dacă s-ar fi realizat înainte de erupția celui de-al doilea molar permanent. Mai mult decât atât, în majoritatea cazurilor, este afişat un overjet normal sau un overbite normal. Extracția nu creează probleme mari în maxilarul superior. $\mathrm{Cu}$ toate acestea, în maxilarul inferior, efectul pierderii de PMP asupra ocluziei depinde de vârsta extracției, iar cele mai bune rezultate au fost găsite la vârstă fragedă (8-10 ani). 
Mai mult decât atât, extracția în maxilarul inferior ar trebui evitată în cazurile cu ocluzie distalizată, deep bite şi overjet mare $(2,7,8$,).

În timpul stadiului de dentiţie mixtă a dezvoltării dentare, stomatologii pot întâlni pacienți cu primii molari permanenți considerați a avea un prognostic nesatisfăcător pe termen lung. În această situație, ar trebui să se ia în considerare extracția dinților şi închiderea spațiului sau utilizarea spațiului de extracție pentru tratamentul ortodontic viitor (10).

\section{CONCLUZII}

Erupția dentară este văzută ca un moment important în evoluția arcadelor dentare.

\section{BIBLIOGRAFIE}

1. Gupta R., Sivapathasundharam B., Einstein A. Eruption age of permanent mandibular first molars and central incisors in the south indian population. Indian J Dent Res. 2007; 18 (4):186-9.

2. Alkhadra T. A Systematic Review of the Consequences of Early Extraction of First Permanent First Molar in Different Mixed Dentition Stages. J Int Soc Prev Community Dent. 2017; 7(5):223-6.

3. Carvalho J.C., Ekstrand K.R., Thylstrup A. Dental plaque and caries on occlusal surfaces of first permanent molars in relation to stage of eruption. J Dent Res 1989; 68:773-779.

4. Alves L.S., Zenkner J.E.A., Wagner M.B. et al. Eruption Stage of Permanent Molars and Occlusal Caries Activity/ Arrest. J Dent Res. 2014; 93(7): 114-9.

5. Mathu-Muju, Kavita R., Kennedy D.B. Loss of Permanent First Molars in the Mixed Dentition:
Există două etape ale erupției în perioada dentației mixte, prima etapă cuprinzând perioada 6-9 ani, care include erupția molarilor primi şi a incisivilor, iar cea de-a doua etapă cuprinzând perioada 9-12 ani, care include erupția caninilor, premolarilor unu şi doi şi molarilor doi.

Primul molar permanent (PMP) este dintele cel mai predispus la carie în dentația mixtă şi permanentă.

Extracția primilor molari permanenţi compromişi poate fi indicată în timpul dentiției mixte, cu toate acestea, un număr de factori pot influența procesul de luare a deciziilor de extracție.

Conflict of interest: none declared Financial support: none declared

Circumstances Resulting in Extraction and Requiring Orthodontic Management. Pediatr Dent. 2016; 38(5):46-53.

6. Baginska J., Rodakowska E., Milewski R. et al. Dental caries in primary and permanent molars in 7-8-year-old schoolchildren evaluated with Caries Assessment Spectrum and Treatment. BMC Oral Helat 2014; 14:74.

7. Jälevik B., Möller M. Evaluation of spontaneous space closure and development of permanent dentition after extraction of hypomineralized permanent first molars. Int J Paediatr Dent. 2007; 17(5):328-35.

8. Albadri S., Zaitoun H., McDonnell S.T. et al. Extraction of first permanent molar teeth: Results from three dental hospitals. Br Dent J. 2007; 203:14.

9. Gill D.S., Lee R.T., Tredwin C.J. Treatment planning for the loss of first permanent molars. 2001; 28(6):304-8. 